\title{
The metamorphism of the Tso Morari ultra-high pressure nappe of the Ladakh Himalaya
}

\author{
Albrecht Steck ${ }^{1 *}$ and Jean-Luc Epard ${ }^{2}$ \\ 1 Institut de Minéralogie et Géochimie, Université de Lausanne, Anthropole, CH-1015 Lausanne, SWITZERLAND \\ 2 Institut de Géologie et Paléontologie, Université de Lausanne, Anthropole, CH-1015 Lausanne, SWITZERLAND \\ * For correspondence, email: albrecht.steck@unil.ch
}

A map of the metamorphic zones of the North Himalayan nappe stack in the Tso Morari region is proposed. The Tso Morari nappe is composed of Late Proterozoic-Cambrian graywackes intruded by the $479 \pm 2 \mathrm{Ma}$ Tso Morari granite and mafic dikes (Girard and Bussy 1999). Eclogites and eclogite relicts testify of an oldest ultra-high pressure metamorphism limited to the deepest Tso
Morari nappe (Epard and Steck 2008). This nappe and the higher Tetraogal, Karzok ophiolite and Mata-Nyimaling-Tsarap nappes are overprinted together by a Barrovian regional metamorphism, that grades from staurolite-kyanite assemblages in the Nuruchan region in the western Tso Morari dome down to metapelites with kaolinite and illite-smectite assemblages in an external zone of

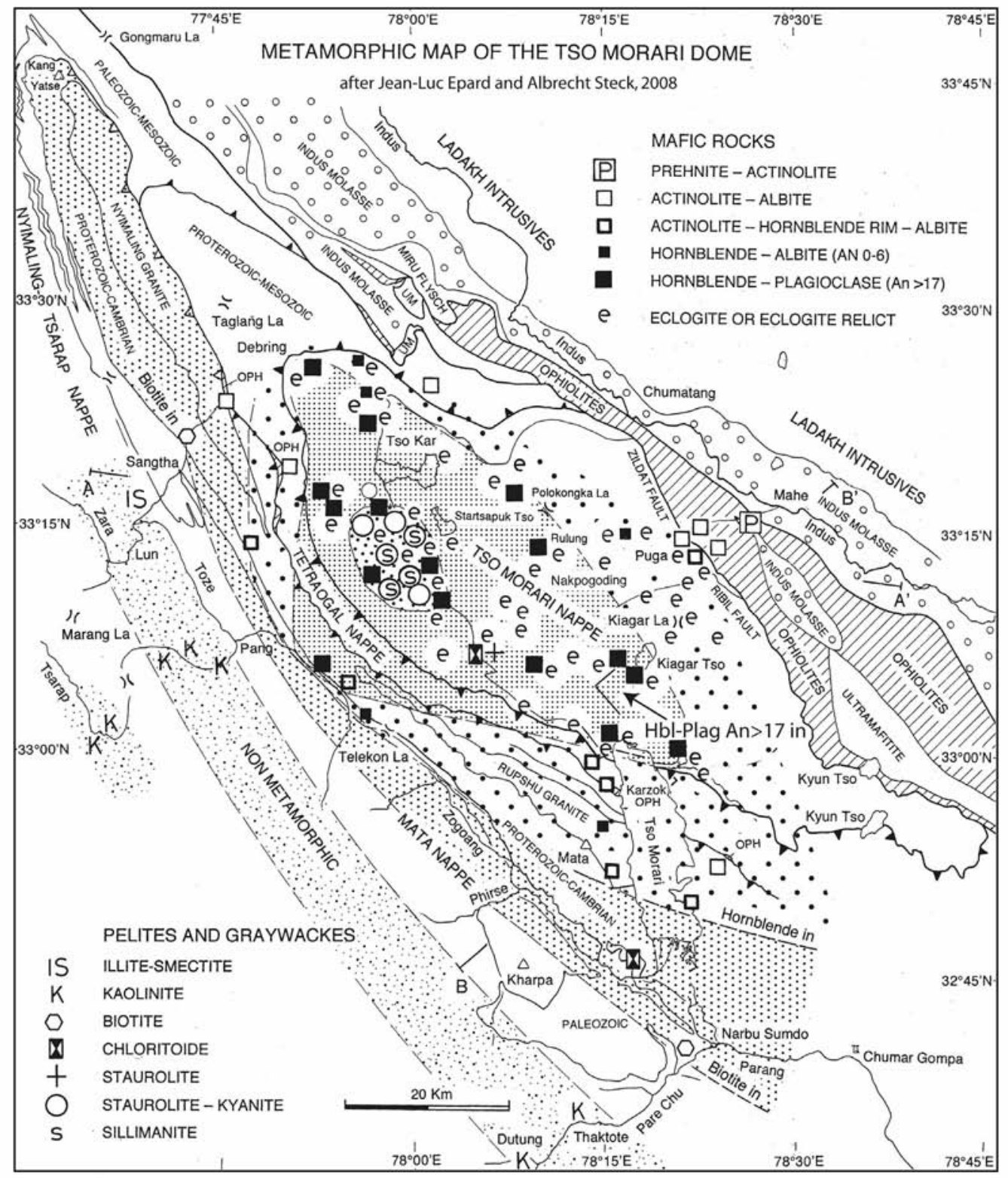


Triassic sediments exposed in the Dutung-Thaktote graben to the SE (Girard 2001, Girard et al. 1999, Steck et al. 1998, Steck 2003). The ultra-high pressure metamorphic rocks with coesite and micro-diamonds are characterized by pressures of over 27 kbars, temperatures of $580 \pm 6^{\circ} \mathrm{C}$ (De Sigoyer et al. 2004, Mukherjee and Sachan 2001 2004). The metamorphism is dated of $53.3 \pm 0.7$ $\mathrm{Ma}$ (Leech et al. 2005). The generally non-oriented fabric of the eclogites testify of the static crystallisation of the metabasites at depth of over $90 \mathrm{~km}$. The detachment and extrusion of the low density Tso Morari nappe, composed of $70 \%$ of the Tso Morari granite and $30 \%$ of graywackes with some eclogitic dikes, occurred by ductile pure and simple shear deformation. It was pushed by buoyancy forces and by squeezing between the underthrusted Indian lithosphere and the Asian mantle wedge (Epard and Steck 2008). The extruding Tso Morari nappe reached a depth of over $35 \mathrm{~km}$ at the base of the North Himalayan accretionary wedge some $48 \mathrm{Ma}$ ago. There, the whole nappe stack crystallized under amphibolite facies conditions with a metamorphic field gradient of $20^{\circ} \mathrm{C} / \mathrm{km}$ (De Sigoyer et al. 2004, Girard 2001). The crystallisation of sillimanite needles parallel to the first stretching lineation L1 and after kyanite testify of a pressure drop during the W-directed extrusion of the Tso Morari nappe (Epard and Steck 2008). Zoned amphiboles with an actinolite core and magnesiohornblende border, or a magnesiohornblende core with a tschermakite border indicate a prograde crystallisation during the Barrovian metamorphism (Schlup et al. 2003).

\section{References}

De Sigoyer J, S Guillot and P Dick. 2004. Exhumationof the ultrahighpressure Tso Morari unit in eastern Ladakh (NW Himalaya): A case study. Tectonics 23: 1-18

Epard J-L and A Steck. 2008. Structural development of the Tso Morari ultrahigh pressure nappe of the Ladakh Himalaya. Tectonophysics: in press.

Girard M. 2001. Metamorphism and tectonics of the transition between non metamorphic Tethyan Himalayan sediments and the North Himalayan Crystalline Zone (Rupshu area, Ladakh, NW India). Mémoires de Géologie (Lausanne) 35

Girard M and F Bussy. 1999. Late Pan-African magmatism in the Himalaya: new geochronical and geochemical data from the Ordovician Tso Morari metagranites (Ladakh, NW India). Schweizerische Mineralogische und Petrographische Mitteilungen 79: 399-417

Girard M, A Steck and P Thélin. 1999. The Dutung-Thaktote extensional fault zone and nappe structures documented by illite crystallinity and clay-mineral paragenesis in the Tethys Himalaya between Spiti river and Tso Morari, NW India. Schweizerische Mineralogische und Petrographische Mitteilungen 79: 419-430

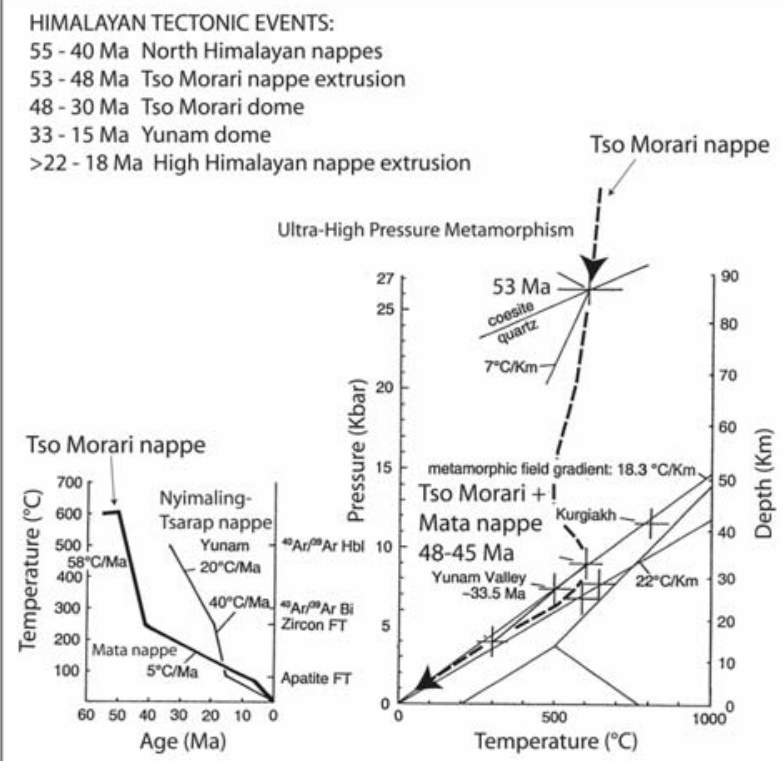

Data from: De Sigoyer (1998), De Sigoyer et al. (2000, 2004), Dezzes et al. (1999), Girard (2001), Girard \& BuSSY (1999) GuILlot Et AL. (1995), LeECH Et AL. (2005), MukHerueE \& SACHAN $(2001,2004)$, Robyr Et AL. (2002, 2006), Schlup (2003), SCHLup et Al. (2003), Steck (2003)

Leech ML, S Sing, AK Jain, RM Klemperer and RM Manickavasagam. 2005. The onset of India-Asia continental collision: early steep subduction required by the timing of UHP metamorphism in the western Himalaya. Earth and Planetary Science Letters 234: 83-97

Muckerjee BK and HK Sachan. 2001. Discovery of Coesite from Indian Himalaya: a record of ultra-high pressure metamorphism in Indian continental crust. Current Science 81:1358-1361

Muckerjee BK and HK Sachan. 2004. Garnet response diamond pressure metamorphism from Tso-Morari region, Ladakh, India. Himalayan Journal of Science 2/4: 209

Schlup M, A Carter, M Cosca and A Steck. 2003. Exhumation history of eastern Ladakh revealed by $40 \mathrm{Ar} / 39 \mathrm{Ar}$ and fission track ages: The Indus river-Tso Morari transect, NW Himalaya. Journal of the Geological Society of London 160: 385-399

Steck A, JL Epard, JC Vannay, J Hunziker, M Girard, A Morard and M Robyr. 1998. Geological transect across the Tso Morari and Spiti areas: the nappe structures of the Tethys Himalaya. Eclogae Geologicae Helveticae 91: 103-121

Steck A. 2003. Geology of the NW Indian Himalaya. Eclogae Geologicae Helveticae 96: 147-196 